\section{Contribution to the} improvement of cotton seed storage at the new textile and cotton industrial company

\section{(SN-CITEC) in Bobo-Dioulasso in Burkina Faso}

\section{Kiessoun Konaté ${ }^{1,2 \star}$, Dominique Ouryagala Sanou ${ }^{1,2}$, Balamoussa Santara ${ }^{1,2}$ and Mamoudou Hama Dicko ${ }^{1}$}

${ }^{1}$ Laboratory of Biochemistry, Biotechnology, Food Technology and Nutrition, Department of Biochemistry and Microbiology, University Joseph Ki-ZERBO, 03 BP 7021 Ouagadougou, Burkina Faso

${ }^{2}$ Faculty of Applied Sciences and Technologies, University of Dedougou, Burkina Faso
Received: 30 September, 2020

Accepted: 27 October, 2020

Published: 30 October, 2020

*Corresponding author: Kiessoun Konaté, Laboratory of Biochemistry, Biotechnology, Food Technology and Nutrition, Department of Biochemistry and Microbiology, University Joseph Ki-ZERBO, 03 BP 7021 Ouagadougou, Burkina Faso, Tel: 0022670766237;

E-mail:mehekiessoum@yahoo.fr

Keywords: Storage; Hygienic quality; Nutritional quality; SN-Citec

https://www.peertechz.com

Check for updates

\begin{abstract}
The oil produced by $\mathrm{SN}$-Citec is a vegetable oil made from cotton seeds. The cotton seeds from the cotton plant go through several stages or workshops to give the oil. To obtain a quality oil, it is necessary to control the physico-chemical parameters such as humidity, water content, acidity level, fat content during the storage of the raw material which is cotton. The objective of our study was to contribute to the improvement of the storage of the raw material at SN-Citec: cotton seed. We determined the physico-chemical parameters of four (4) batches of seed after storage. The values obtained were compared to the standards of the codex stand. Thus standard methods were used to evaluate the quality of storage. The results of the analyses of the parameters during storage varied from $4.84 \%$ to $5.80 \%$ for the water content, $4.77 \%$ to $4.94 \%$ for the moisture content, $2.53 \%$ to $3.65 \%$ for the acidity content and $20.28 \%$ to $20.45 \%$ for the oil content of the seed. All the results found were in accordance with codex standards and the values in the laboratory's archives. This study showed that the oil from SN-Citec is of good quality so to obtain an oil of hygienic and nutritional quality a good method of conservation of the raw material, a check of the moisture content of the seed before and during storage, a reserved environment and a good internal temperature of the materials during storage are important.
\end{abstract}

\section{Introduction}

Cotton (Gossypium hirsutum) is an important industrial crop worldwide and the predominant natural fiber in the textile industry. Despite competition with artificial fibers, cotton remains important and accounted for $30 \%$ of the more than 82 million tons of textile fibers processed in 2013. Burkina Faso's industry is essentially manufacturing and oriented towards the processing of local raw materials. Among local raw materials, the oilseed sector, particularly the cotton sub-sector, is the most represented. It is Burkina Faso's second largest export sector after gold. The country therefore has a very good regional position as a seed cotton producing country [1]. Cotton seed production increased from 115,000 tons in 1985 to 631,000 tons in 2005. This sector thus represents a considerable economic stake for the country. Moreover, among the challenges facing the African cotton sector in general and that of Burkina Faso in particular is the issue of local processing of the cotton fiber and seed produced $[1,2]$. Thus, emphasis has been placed in particular on the agri-food sector [3]. Nowadays, several food processing 
units have been born in our country, especially oil mill units. Most of these companies have made huge investments to set up a workshop for receiving and storing cotton seeds in order to modernize their production infrastructure. The SN-Citex has a cylindrical tank called silo, two sheds and a terraced air for storing cotton seed. Seed storage is the beginning of the oil mill chain and determines the quality of the oil. At the SN-Citex the cotton seeds are then stored in the silo after analysis of certain number of parameters such as moisture,acidity. Then they are dried during the month of February and March in a open air under and equipped space and finally they are deposited in bulk under a hangar.These operation should make it possible to preserve the original quality of the cotton. If the cotton seed received by SN-Citex is good then it is necessary to ensure that the storage conditions do not compromise the quality of the finished product and that the seed has kept its original quality. It is in this perspective that this work was undertaken on the theme: "Contribution to the improvement of cotton seed raw material storage at SN-Citec". Thus, the objective of our work was to determine the physical and chemical parameters around storage in order to control the factors influencing storage and to take corrective measures.

\section{Material and methods}

\section{Study area}

Our study was carried out at the new company of oil and soap (SN Citec) located in the industrial zone 19, rue 20.231 Bobo Dioulasso. It was created in 1995 and is the first agroindustry in Burkina Faso.

\section{Biological material}

The cotton seeds used for this study came from the different ginning factories of the Fibers and Textile company or Gourma cotton company for them, these seeds constitute a vegetative waste.

\section{Experimental materials}

We used an oven $103^{\circ} \mathrm{C}_{ \pm} 2^{\circ} \mathrm{C}$, a precision analytical balance $\pm 0,001 \mathrm{~g}$ and a desiccator to determine the moisture, acidity and fat content of seed batches. In addition, petri dishes were used to determine in particular the moisture content of the seed. A magnetic stirrer, a hot plate, $50 \mathrm{ml}$ measuring cylinder, $95^{\circ}$ alcohol, 0.1N NaOH, 250ml Erlenmeyer flask, phenolphthalein, $250 \mathrm{ml}$ beakers, magnetic bars were also used to determine the acidity level of the seed and Soxhlets,mechanical mill, filter paper, extraction conductor, 200 to $250 \mathrm{ml}$ flasks, hexane, $250 \mathrm{ml}$ beakers were used to determine the fat content.

\section{Sampling}

In the course of our work we have selected four (4) seed lots. We took three samples per lot every week. The collected seeds were put in appropriate plastic bags and transported directly to the laboratory for analysis.

\section{Analysis of storage parameters}

\section{Determination of the moisture content of the seed}

The water content was determined according to the standard method NF EN ISO 662 (2016) [4]. The seed was therefore heated in an oven at $103 \pm 2{ }^{\circ} \mathrm{C}$ until the water was completely eliminated in order to determine the loss of mass. At least three measurements were made and the arithmetic mean of these different measurements was calculated.

The moisture content of the seeds was given as a percentage by the following formula:

$$
\text { Moisture content }=\frac{\mathbf{M} 2-\mathbf{M} 1}{\mathbf{M} 1-\mathbf{M}} \times 100
$$

With: $M$ is the weight of the petri dish in grams, $M 1$ is the weight of the petri dish + the mass of the test sample in grams before drying, M2 is the weight of the petri dish + the mass of the test sample in grams after drying.

\section{Determination of the acidity level}

The acidity level is the measure of free fatty acids. It has been determined thanks to the international standard NF EN ISO 660 ) [5]. At least three measurements were carried out and the arithmetic mean of these different measurements was calculated.

\section{The expression of the acidity results was:}

$$
\text { Acidity level }(\%)=\frac{\mathrm{V} \times \mathrm{N} \times 282}{\mathrm{PE}} \times 100
$$

With : V the volume of soda poured to obtain the coloured indicator; $\mathrm{N}$ the concentration of the soda solution; $\mathrm{PE}$ the mass of the test sample; 282 : the molecular weight of the oleic acid.

\section{Determination of the fat content of cottonseed}

The fat content is the percentage of oil that can be extracted from this seed. It has been standardised according to the international standard NF EN ISO104 [6]. At least three measurements were made and the arithmetic mean of these different measurements was calculated.

The method of calculating the fat content of cottonseed was as follows:

$$
\text { Fat content }(\%)=\frac{\mathrm{P} 2-\mathrm{P} 1}{\mathrm{PE}} \times 100
$$

Hence: P1 the weight of the empty flask in grams, P2 the weight the flask containing the extracted fat in grams, PE the mass of the Test Sample.

\section{Results and discussion}

\section{Water content of the cotton seed per month (May and June)}

The water content of the seed of the lots is presented in Table 1. It varies from 4.84 to 5.80 and is close to the codex alimentarius standard (06\%). These values could be explained by good seed storage at an adequate temperature, so it can be said that the storage place did not have a major impact on 
Table 1: Water content of cotton seed during storage.

\begin{tabular}{|c|c|c|}
\hline $\begin{array}{c}\text { Different } \\
\text { batches }\end{array}$ & $\begin{array}{c}\text { Average } \\
\text { percentage } \\
\text { value(\%) }\end{array}$ & $\begin{array}{c}\text { Limit value in percentage (\%) according to } \\
\text { the codex alimentarius standard }\end{array}$ \\
\hline lot1 & 4,94 & $<06$ \\
\hline lot2 & 4,78 & $<06$ \\
\hline lot3 & 5,80 & $<06$ \\
\hline lot4 & 4,84 & $<06$ \\
\hline
\end{tabular}

the water content of the seed. Moreover, these quantities of water could be important to guarantee the quality of the seed which will be used to obtain an oil suitable for consumption [7]. Indeed, water plays a role as an accelerating factor in enzymatic (lipases and lipoxygenases) and non-enzymatic (Maillard reactions) reactions during storage. Delacharlerie, et al. [8] has shown that lipase catalyses the hydrolysis of triglycerides contained in the seed in the presence of water, while lipoxygenation catalyses the oxidation of free fatty acids in the presence of molecular oxygen and is also a precursor of acidity. However, if the amount of water is not controlled, the seed may germinate, its fat content may decrease and it may self-ignite.

From Figure 1 we observed that the moisture content varied from 4.77 to 4.94 . There was also a high moisture content in lots 1 and 4, which also contained a fairly high amount of water compared to the other samples (Table 1). The amount of water is therefore proportional to the moisture content. According to Cisse [9] the moisture content of the seed is directly related to the moisture content. The wetter the seeds are, the more likely it is that a high moisture content will be observed [9]. Good seed drying and storage may help to reduce this value [9]. Similarly, the results found during the months of May and June were close to those of the laboratory archive (December 2014, January and February 2015) in the reception phase. These values are recorded in Table 2 . This could be explained by the fact that the seeds were well dried and the internal temperature as well as the humidity of the storage place had been controlled [10]. The humidity level was also high during the months of December and January. This could be due to the temperature and the beings living in the storage environment. In fact they can through respiration influence the humidity of the environment and therefore the moisture content of the seed.

\section{Acidity of the cotton seed}

According to Table 3 the acidity values of the seed vary from 2.53 to 3.65 and are below the codex alimentarius standard $(06 \%)$ and the Burkinabe standard $[6,11]$. These data obtained reflect the fact that some inconveniences, the main ones being unpleasant odour and taste, and enormous losses in refining had been avoided. Kassamba [12] had shown that the acidity level of the cotton seed is favoured by moisture or humification of the seed or by seed ageing. We could conclude that the seeds used in our study were young and were stored at a good temperature.

Table 4 shows the acidity level of the seed during storage from December to June. The results for May and June were also in accordance with the NBF standard and the Codex Alimentarius $[6,11]$. Moreover, they are similar to those in the laboratory's archive during the reception of the cottonseed. Given that moisture favours acidity according to Kassamba [12] this could mean that there was no major variation in seed moisture over the last few months.

\section{Fat content in cotton seed}

Table 5 indicates that the fat content results were in the range 20.28 to $24.45 \%$. These values are considered normal the better they are lower than the codex alimentarius standard according to which the oil content of cottonseed is 20 to $24 \%$ and the Burkinabe standard [5,9]. These results of the fat content could be explained by mature, non-mouldy seeds and good drying of these seeds. We had also noted in Table 6 that the results found during the months of May and June were similar to those found in the laboratory's archive during the first three

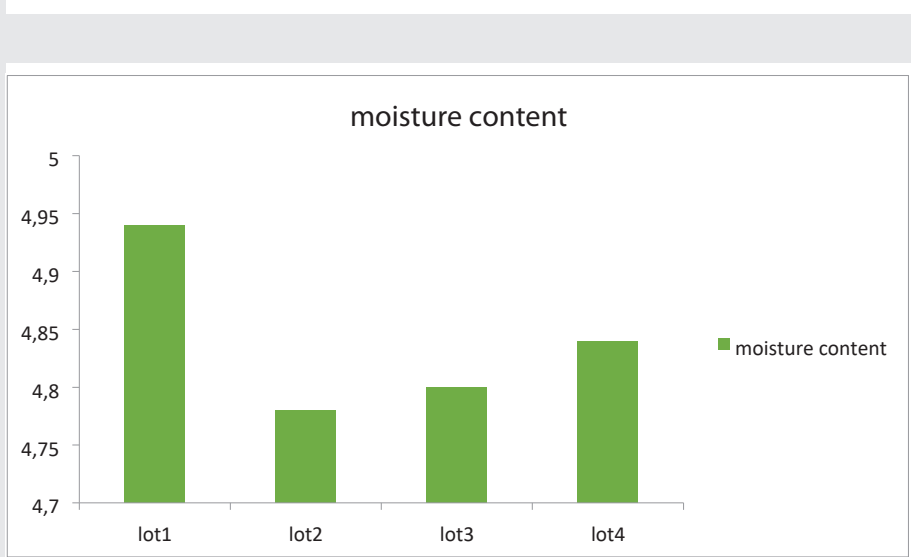

Figure 1: Histogram of the seed moisture content of the different lots.

Table 2: Moisture content of the cotton seed of the different months.

\begin{tabular}{|c|c|c|c|c|c|c|}
\hline Month & $\begin{array}{c}\text { December } \\
\mathbf{2 0 1 4}\end{array}$ & January & February & May & June & $\begin{array}{c}\text { Limit value in percentage } \\
\text { (\%) }\end{array}$ \\
\hline $\begin{array}{c}\text { Average } \\
\text { humidity } \\
\text { value }\end{array}$ & 5,75 & 5,09 & 4,70 & 4,90 & 4,78 & $<06$ \\
alimentarius standard
\end{tabular}

Table 3: Acidity level of the graine.

\begin{tabular}{|c|c|c|}
\hline Various & $\begin{array}{r}\text { Average percentage } \\
\text { value(\%) }\end{array}$ & $\begin{array}{c}\text { Limit value in percentage (\%) } \\
\text { according to the codex alimentarius } \\
\text { standard }\end{array}$ \\
\hline lot1 & 3,65 & $<06$ \\
\hline lot2 & 3,36 & $<06$ \\
\hline lot3 & 3,42 & $<06$ \\
\hline lot4 & 2,53 & $<06$ \\
\hline
\end{tabular}

Table 4: Cotton seed acidity of different months.

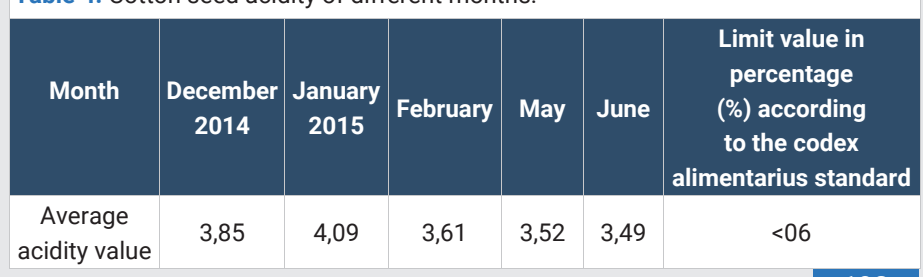


months of receipt. This could be explained by the fact that the temperature during these months was favourable for the maintenance of the seeds. The humidity of the environment was acceptable so the temperature was acceptable which did not impact the fat content of the seed.

Figure 2 shows that the oil content of the seed, the moisture content and the acidity level were proportional and therefore dependent on each other.

\section{Cotton seed temperature}

Both the stored seed and the organisms that attacked it are living, breathing beings. During respiration, oxygen was used and carbon dioxide, water and heat were produced. The amount of carbon dioxide, water and heat produced during respiration depended on the temperature and moisture content of the seed. In fact, the moisture produced during respiration increased the moisture content of the product while the heat produced increased the temperature. The increases in temperature and humidity created the conditions for the seed to burn. On the other hand, the level of respiration of well-dried cotton seeds at a low moisture content did not cause any increase in temperature. The higher the temperature, the lower the

Table 5: Oil content of the cotton seed.

\begin{tabular}{|c|c|c|}
\hline $\begin{array}{c}\text { Different } \\
\text { batches }\end{array}$ & $\begin{array}{c}\text { Average percentage } \\
\text { value(\%) }\end{array}$ & $\begin{array}{c}\text { Limit value in percentage (\%) } \\
\text { according to the codex alimentarius } \\
\text { standard }\end{array}$ \\
\hline lot1 & 20,42 & $20-24$ \\
\hline lot2 & 20,45 & $20-24$ \\
\hline lot3 & 20,39 & $20-24$ \\
\hline lot4 & 20,28 & $20-24$ \\
\hline
\end{tabular}

Table 6: Oil content of cottonseed in different months.

\begin{tabular}{|c|c|c|c|c|c|c|}
\hline Month & $\begin{array}{c}\text { December } \\
2014\end{array}$ & $\mathbf{2 0 1 5}$ & February & May & June & $\begin{array}{c}\text { Limit value in } \\
\text { percentage (\%) } \\
\text { according to the }\end{array}$ \\
\hline $\begin{array}{c}\text { Average value } \\
\text { of the oil } \\
\text { contex alimentarius } \\
\text { standard }\end{array}$ \\
$\begin{array}{c}\text { cont of the } \\
\text { seed }\end{array}$
\end{tabular}

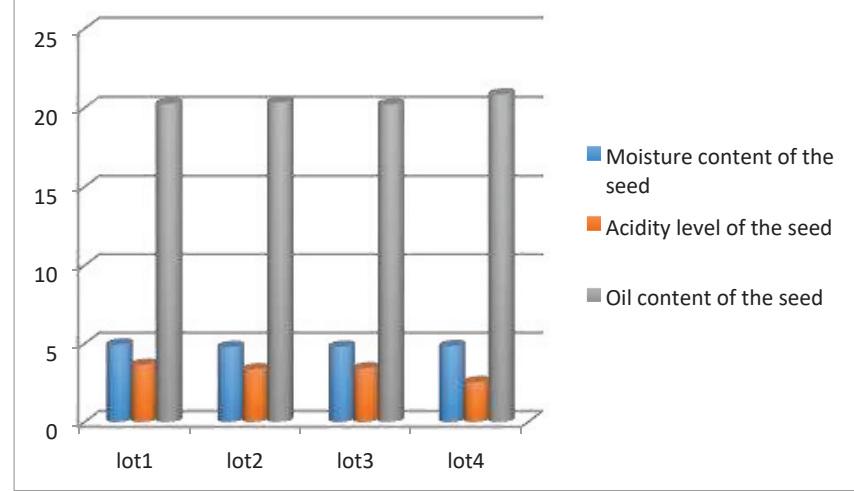

Figure 2: Histogram of the various parameters searched in batches. moisture content had to be in order to reduce spoilage and the lower the temperature, the higher the moisture content can be [13].

Temperature, like other factors, had to be controlled during storage to avoid huge seed losses. The studies in [8,14-18]. showed that this parameter had to be taken into account in order to obtain a quality oil with no effect on human health.

\section{Conclusion}

For a seed of very good physical and/or chemical quality, the quality control analyses in the laboratory and on the storage premises have been carried out. The targeted steps are the critical points, as any failure can create hazards that can reach unacceptable limits. The materials used, the method of conservation, checking the humidity of the seed before and during storage, the reserved environment and the internal temperature of the materials during storage are the critical points when storing cotton seed. This study was designed to contribute to the improvement of the storage of the raw material at SN Citec: cotton seed. In view of the results we reached during the analyses on cotton seed, it is clear that the raw material "cotton seed" used by SN Citec is of good quality. Indeed, the moisture, acidity and oil content values analysed during our study complied with the standards of the codex stand. Nevertheless, the monitoring measures must be well applied in order to always guarantee the quality of the seed. In addition to this, the corrective actions implemented must always be respected.The storage of the cotton seed in normal physicochemical condition will minimised losses and breakage during the production of oil.It also allow us to complete on the market the the original qualities of our products and avoid their attack by insects, mold.

\section{References}

1. Berti F, Hofs JL, Zagbaï HS, Lebailly P (2006) Cotton in the world, the place of African cotton and key issues. Biotechnology, Agronomy and Society and Environment 10: 271-280.

2. Hussein K, Perret C, Hitimana L (2005) Economic and social importance of cotton in West Africa: The role of cotton in development, trade and livelihoods. Ocde Sahd/D 556: 103-115. Link: https://bit.ly/2HDubwZ

3. Sontie V (2015) Cottonseed oil production technology. COipS technology fat End of cycle memory. Catholic University of West Africa (UCAO); 32.

4. NF EN ISO 660 (2009) Fats of animal and vegetable origin - Determination of acid number and acidity.

5. NF EN ISO 662 (2016) Fats of animal and vegetable origin - Determination of water and volatile matter content.

6. NF EN ISO 104(1988) Fats of animal and vegetable origin - Determination of fat content.

7. Pomeranz Y, Meloan C (1994) Food Analysis: Theory and Pratice. Dans 3rd Ed Chapman et Hall. New York.

8. Delacharlerie $S$, de Biourge $S$, Chèné $C$, Sindic $M$, Deroanne $C$ (2008) Organoleptic HACCP: a practical guide. Published with the help of the Ministry of the Walloon Region (Belgium), 176.

9. Cisse ML (2010) Characterisation of crude vegetable oils from West African oilseeds as fuel (Master Thesis). Dissertation for the Specialised Master's Degree in Biological Engineering, Nazi Boni University 1-52. 
10. Compaore B (2014) Influence of drying methods on tomato quality séchée Comparative study of solar and gas dryers. Dissertation for Master's Degree in Science and Technology, University of Ouagadougou 53.

11. Codex-Alimentarius (1992) Values and limits of cottonseed parameters (fat).

12. Kassamba B (2002) Good laboratory practice and quality control in oil mills.

13. Scheepens P, Hoevers R, Arulappan FX, Pesch G (2011) Storage of agricultura products. Agrodok Series 31, CTA, 82. Link: https://bit.ly/3kHAldG

14. Traore SM (2012) Contribution to the elaboration of the HACCP plan of the packaging workshop of Société Nouvelle citec : construction of the HACCPI control panel. Dissertation for the Master's Degree in Science and Technology, University of Ouagadougou 70.
15. Afnor (2011) Determination of water and other volatile matter content. Fatty bodies of Animal and Plant origin 1-13.

16. Sarr D (n.d.) Use of the wild diploid species Gossypium australe F. Muell For the improvement of the cultivated tetraploid species $\mathrm{G}$. hirsutum L. by the method of monosemic addition lines. -Europe. Thesis of Doctor of Agronomic Sciences and Biological Engineering, University of Wallonia-Europe, 1-2.

17. Tran G, Française A (1994) Cotton and its co-products in animal feed. Food Animals 6-8.

18. NBF 001-005 (2019) Catalogue of Burkinabe standards.
Discover a bigger Impact and Visibility of your article publication with Peertechz Publications

\section{Highlights}

* Signatory publisher of ORCID

* Signatory Publisher of DORA (San Francisco Declaration on Research Assessment)

* Articles archived in worlds' renowned service providers such as Portico, CNKI, AGRIS, TDNet, Base (Bielefeld University Library), CrossRef, Scilit, J-Gate etc.

* Journals indexed in ICMJE, SHERPA/ROMEO, Google Scholar etc.

- OAI-PMH (Open Archives Initiative Protocol for Metadata Harvesting)

* Dedicated Editorial Board for every journal

* Accurate and rapid peer-review process

* Increased citations of published articles through promotions

- Reduced timeline for article publication

Submit your articles and experience a new surge in publication services (https://www.peertechz.com/submission).

Peertechz journals wishes everlasting success in your every endeavours.

Copyright: @ 2020 Konaté K, et al. This is an open-access article distributed under the terms of the Creative Commons Attribution License, which permits unrestricted use, distribution, and reproduction in any medium, provided the original author and source are credited.

Citation: Konaté K, Sanou DO, Santara B, Dicko MH (2020) Contribution to the improvement of cotton seed storage at the new textile and cotton industrial company (SN-CITEC) in Bobo-Dioulasso in Burkina Faso. Int J Agric Sc Food Technol 6(2): 190-194. DOI: https://dx.doi.org/10.17352/2455-815X.000073 